Vietnam Academy of Science and Technology
(VAST)

\title{
An analysis of forest biomass changes using geospatial tools and ground survey data: a case study in Yok Don national park, Central Highlands of Vietnam
}

\author{
Nguyen Viet Luong ${ }^{1}$, Ryutaro Tateishi ${ }^{2}$, Nguyen Thanh Hoan $^{3}$, To Trong Tu${ }^{1}$, Le Mai Son ${ }^{1}$ \\ ${ }^{1}$ Space Technology Institute, Vietnam Academy of Science and Technology, Hanoi, Vietnam \\ ${ }^{2}$ Center for Environmental Remote Sensing, Chiba University, 1-33 Yayoi-cho, Inage-ku, Chiba-shi, Japan \\ ${ }^{3}$ Institute of Geography, Vietnam Academy of Science and Technology, Hanoi, Vietnam
}

Accepted 25 December 2014

\begin{abstract}
Vietnam conducts a national forest survey every five years using optical satellite imagery as Landsat, SPOT satellites and ground survey data. However, estimation of change in biomass due to change in forest types has not been of research interest despite of its importance in the face of climate change and applicability for REDD implementation. In this study, we used SPOT HRV satellite data of 2004, 2011 and ground survey data for analysis of changes in biomass of forest cover in Yok Don National Park, Central Highlands of Vietnam. This method has been effectively employed for mapping of land cover with overall classification accuracy of $84.30 \%$ to $86.63 \%$. The results demonstrated that between 2004 and 2011, the biomass of Evergreen broad leaved rich forest decreased by 2.95 Megatons, biomass of the Evergreen broad leaved medium forest decreased by 0.09 Mega tons and biomass of the Dry open dipterocarps medium forest decreased 2.20 Mega tons. In that period, biomass of the Evergreen broad-leaved poor forest increased by 0.02 Mega tons and biomass of the Dry open dipterocarps-poor forest increased by 0.91 Mega tons.
\end{abstract}

Keywords: Satellite data, SPOT HRV, land cover change, tropical forest biomass.

(C) 2014 Vietnam Academy of Science and Technology

\section{Introduction}

Forest ecosystems play a very important role in the global carbon cycle, the $\mathrm{CO}_{2}$ from the atmosphere is take up by vegetation and stored as plant biomass (Bhishma et al., 2010; Phat, N.K. et al., 2004). For this reason, the UNFCC and its Kyoto Protocol recognized the role of forests in $\mathrm{CO}_{2}$ sequestration. Specifically, Article 3.3 and 3.4 of the Kyoto Protocol pointed out forest as potential carbon storage (Guide to the Kyoto Protocol to United Nations framework convention

"Corresponding author, Email: nvluong@sti.vast.vn on climate change, 1998) and currently is the UN-REDD+ program.

The UN-REDD programs are being carried out in nine countries including Vietnam. Under the REDD mechanism, countries will need to measure and monitor the emissions of $\mathrm{CO}_{2}$ resulting from deforestation and degradation within their borders. In other words, the countries participating in this program should have a system: "Measurement, Evaluation and Report" system (MRV) (UNREDD in Vietnam program, 2012). Nowadays, many studies in the world have demonstrated that: Remote sensing techniques have many advantages 
Nguyen Viet Luong, et al./Vietnam Journal of Earth Sciences 36 (2014)

in biomass estimation over traditional field measurement methods, so, remote sensing is deemed to be a key technology involving in existing efforts to monitor the carbon pool and fluxes (Lu D. S., 2006). However, in Vietnam the application of remote sensing in the study of natural resource and in the forest vegetation biomass, carbon storage and $\mathrm{CO}_{2}$ sequestration has been limited, done due to shortage of data/asynchronous and especially, lack of the highquality experts. Vietnam conducts a national forest survey every five years using optical satellite imagery from Landsat, SPOT satellites, and ground survey data. Hence, forest cover estimation has been periodically assessed. However, estimation of change in biomass due to change in forest types has not been of research interest despite of its importance in the face of climate change and applicability for REDD implementation.

Considering of the data conditions of Vietnam today, a study for using the optical satellite imagery with a medium spatial-resolution data as well as satellite imagery from SPOT satellite and ground survey data to study the forest cover, plant biomass, carbon storage and $\mathrm{CO}_{2}$ sequestration í essential. Therefore, this research aimed to fulfill an important research gap by estimating quantity and direction of change in forest types and its effect on biomass in tropical forests. This approach used in this study effectively applies geospatial techniques and ground survey data for estimating change in forest cover and biomass and has potential to be adopted elsewhere. Therefore, this study is meaningful with regard to the current developments regarding Vietnam's first remote sensing satellite-VNREDSat 1, which is an optical earth-observation satellite capable of capturing images on all areas on the earth's surface.

\section{Study area}

The Yok Don national park is located Dak Lak province in the Central Highlands. It is one of the largest national park in Vietnam. The study area lies between; $12^{\circ} 45^{\prime} \mathrm{N}-13^{\circ} 10^{\prime} \mathrm{N}$ latitude and $107^{\circ} 29^{\prime} \mathrm{E}-107^{\circ} 48^{\prime} \mathrm{E}$ longitude (Figure 1). Most of the park lies at $\sim 200 \mathrm{~m}$ elevation and the terrain is relatively flat. There are, however, several ranges of low hills within the national park, the highest point of which is the eponymous Mount Yok Don at $482 \mathrm{~m}$ in the south-eastern range (Canh, N. X. et al., 2009, Thin, N. N. et al., 2007). Total area is 115.5 thousand ha.

Flora at Yok Don national park is dominated by species of Dipterocarpaceae family, including Dipterocarpus tuberculatus, D. obtusifolius, Shorea obtuse etc. However, the Anacardiaceae, Combretaceae, Fabaceae and Myrtaceae families are also well represented. Evergreen forest are distributed in higher elevations on the south-east slopes in the national park. These forest types are denser, and are dominated by the species from families as Fagaceae, Euphorbiaceae, Sapindaceae, Ebenaceae and Meliaceae (Anon. 1998). According to Thin (2007), 854 vascular plant species belonging to 129 families have been recorded in the national park (Thin N. N. et al., 2007).

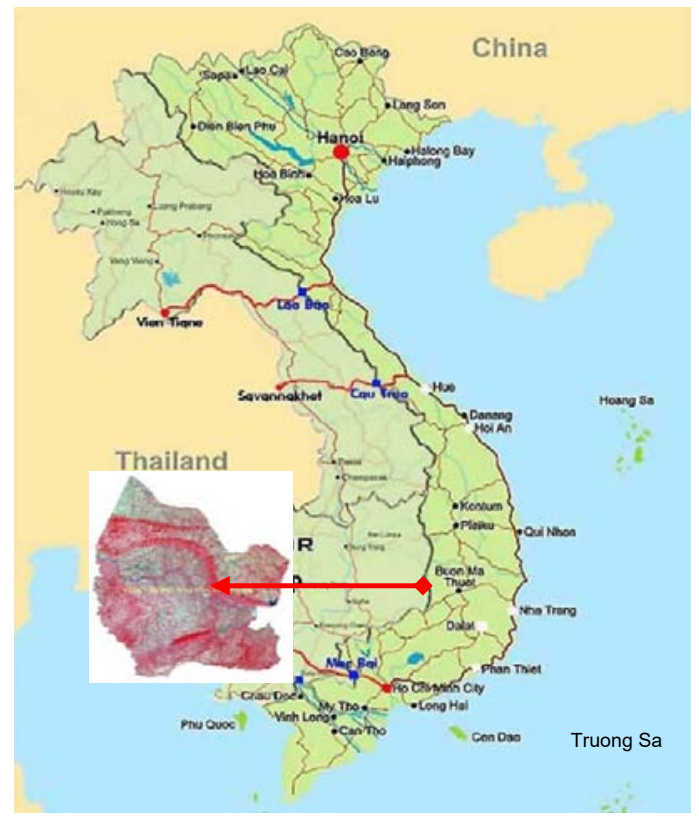

Figure 1. Location of the study area

\section{Data and Methodology}

\subsection{Satellite data}

The study has used the satellite imagery of SPOT-5 (Système Probatoire de 1'Observation de la Terre) with $10 \mathrm{~m}$ spatial resolution in May 2004 
Vietnam Journal of Earth Sciences 36 (2014) 439-450

and 2011. Moreover, this month is start of the rainy season in the Central Highlands region of Viet Nam that means that plants growth luxuriant, especially the deciduous species. The technical details of the satellite data used in the present study are given in Table 1 and Figure 2.

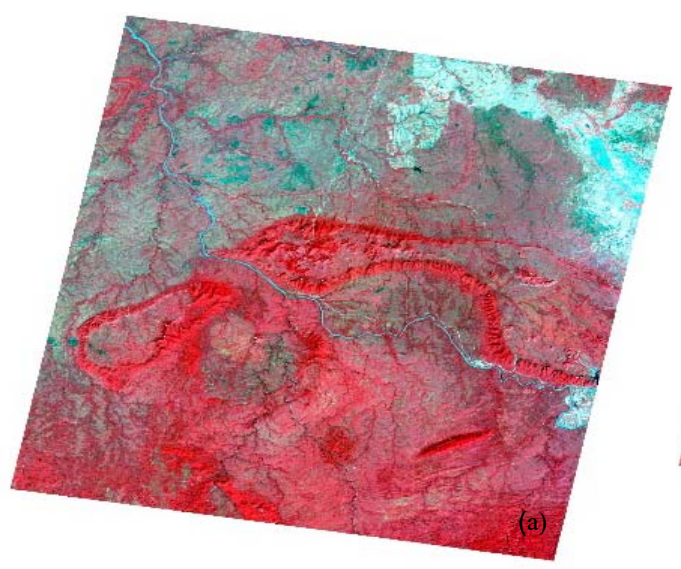

Table 1. Details of satellite data used in the study

\begin{tabular}{|c|c|c|c|c|c|c|}
\hline No. & Satellite & Sensor & $\begin{array}{c}\text { Date of } \\
\text { pass }\end{array}$ & $\begin{array}{r}\text { Total } \\
\text { bands } \\
\end{array}$ & $\begin{array}{c}\text { Spectral } \\
\text { bands used } \\
\end{array}$ & $\begin{array}{c}\text { Spatial } \\
\text { resolution }(\mathrm{m})\end{array}$ \\
\hline 1 & Spot 5 & HRV & $\begin{array}{l}\text { May } \\
2004\end{array}$ & 3 & $1,2,3$ & 10 \\
\hline 2 & Spot 5 & HRV & $\begin{array}{l}\text { May } \\
2011\end{array}$ & 3 & $1,2,3$ & 10 \\
\hline
\end{tabular}

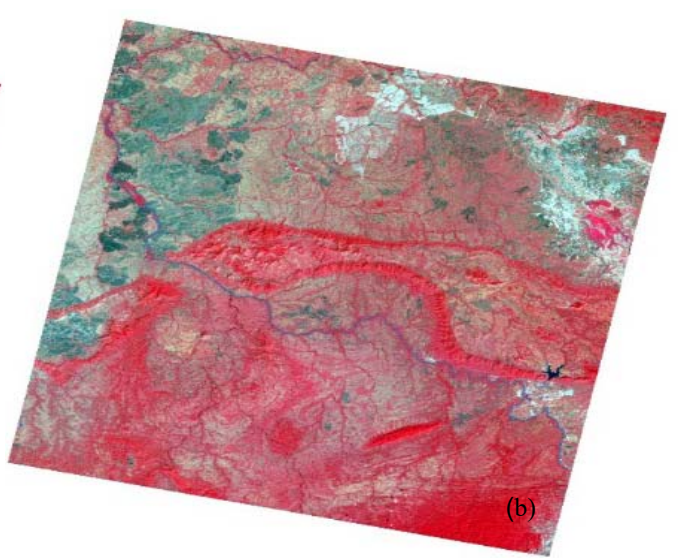

Figure 2. SPOT HRV False Colour Composite (a) 2004, (b) 2011

\subsection{Satellite image processing}

The method of satellite image processing was used in this study including as Geometric correction; Image to map rectification; Image to Image registration; Change detection analysis used Post classification comparison method (based onsupervised classification) was adopted for change analysis.

\subsection{Field work}

In this study, a typical sample plot of $500 \mathrm{~m}^{2}$ was used for Dry open dipterocarps and $1000 \mathrm{~m}^{2}$ was used for Evergreen broad-leaved forest. At each sample plot various information on the individual woody trees such as name of tree species (local and scientific names), Breast height diameter at $1.3 \mathrm{~m}$ position $\left(\mathrm{D}_{1.3}>5 \mathrm{~cm}\right)$ and height of trees were recorded (Figure 3). Additionally, one hundred seventy two locations were considered as ground check for accuracy assessment.

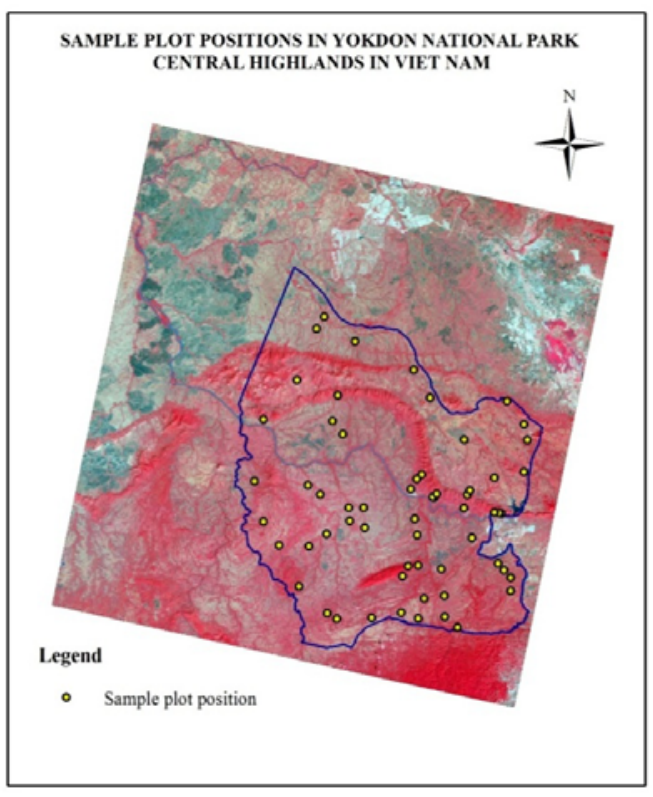

Figure 3. Sample plot position in study area 
Nguyen Viet Luong, et al./Vietnam Journal of Earth Sciences 36 (2014)

\subsection{Forest cover classification}

Originally, the forest cover in this ecosystem zone was classified in to 6 classes. However, as the results of this investigation indicate, one of the original classes, DD rich forest, does not exist in the study area. Therefore, the forest cover of the study area was classified into the 5 main classes as (1) EB rich forest, (2) EB medium forest, (3) EB poor forest, (4) DD medium forest and (5) DD poor forest, because DD rich forest does not exist in the study area. Additionally, other land cover categories may be identified as- (6) Other land (mainly composed of woody tree from 0.5 to $5 \mathrm{~m}$ tall); scrubland, (most of the individual shrubs not touching each other, often with a grass stratum); Thicket (individual shrubs interlocked and barreland) (UNESCO Paris. International classification and mapping of vegetation, 1973) and (7) Water body. This study adopted classification criteria of the UNESSCO (1973) (UNESCO Paris. International classification and mapping of vegetation, 1973) and the Circular 34/TT-BNN issued by MARD (2009) (Ministry of Agriculture and Rural Development (MARD), 2009). The rich forest comprised a forest with a standing wood volume over $200 \mathrm{~m}^{3} /$ ha, the medium forest with 101 $200 \mathrm{~m}^{3} / \mathrm{ha}$ and the poor forest included the forest with $10-100 \mathrm{~m}^{3} / \mathrm{ha}$. This classification schemes allows forest managers to easily identify different land cover types and use for management purpose, Table 2.

Table 2. Classification of land cover for the study area

\begin{tabular}{ll}
\hline \multicolumn{1}{c}{ UNESSCO (1973) } & \multicolumn{1}{c}{$\begin{array}{c}\text { Circular 34/TT-BNN } \\
\text { issued by MARD (2009) }\end{array}$} \\
\cline { 2 - 2 } $\begin{array}{l}\text { Evergreen broad-leaved forest (EB } \\
\text { forest) }\end{array}$ & 1. EB rich forest \\
Dry open Dipterocarps forest (DD & 3. EB poor forest \\
forest) & 4. DD medium forest \\
Other land cover & 5. DD poor forest \\
Water body & 6. Other land cover \\
\hline
\end{tabular}

\subsection{Method for determining forest biomass}

This study applied the allometric equation (1) and (2) developed for the estimate of above ground biomass of Evergreen broad-leaved forest and Dry open dipterocarps forest. These allometric equations for estimating biomass (correlation model) were developed by the UN-REDD program in 2012 (UN-REDD in Vietnam program. Guidelines on Destructive Measurement for Forest Biomass Estimation for technical staff use. (Version for discussion), 2012; UN-REDD Vietnam Program. Tree allometric equation development for estimation of forest above-ground biomass in Viet Nam. Part A - Introduction and Background of the Study Viet Nam, 2012) that followed the guideline of IPCC reports (2003, 2006).

For Evergreen broad-leaved forest is:

$$
\mathrm{AGB}=0.0530 *\left(\mathrm{D}^{2} * \mathrm{H}^{0.7}\right)^{1.0072}
$$

For Dry open dipterocarps forest is:

$$
\mathrm{AGB}=0.0154 *\left(\mathrm{D}^{2} * \mathrm{H}^{0.7}\right)^{1.1682}
$$

Where:

$$
\begin{aligned}
& \text { AGB - Above ground tree biomass } \\
& \text { D - Diameter at breast height of tree } \\
& \text { H - Height of tree stand }
\end{aligned}
$$

The result of this study are then compared with the results suggested by Brown (1997), Chave et al (2005), Bao Huy (2008), Bhishma et al. (2010), Chaiyo et al. (2011) from the similar studies.

\section{Results}

\subsection{The parameter of structure and biomass of forest cover}

This study focuses on the current state of large forest biomass. The results from the ground survey data of 60 sample plots were used to calculate the parameters of structure and biomass for the current state of five forest cover types at Yok Don National Park include the Breast height diameter at $1.3 \mathrm{~m}$ position, $\left(\mathrm{D}_{1.3}>5 \mathrm{~cm}\right)$, height at from bottom to top of wood tree $\left(\mathrm{H}_{\mathrm{vn}}\right)$, height of wood tree under branch $\left(\mathrm{H}_{\mathrm{dc}}\right)$, density of wood tree/ha $(\mathrm{N} / \mathrm{ha})$, basal area average/ha $(\Sigma \mathrm{G} / \mathrm{ha})$. The results are shown in the Table 3. 
Vietnam Journal of Earth Sciences 36 (2014) 439-450

Table 3. The parameters of the structure of forest cover

\begin{tabular}{|c|c|c|c|c|c|c|c|}
\hline No. & Class & $\begin{array}{l}\mathrm{D}_{1.3} \\
(\mathrm{~cm})\end{array}$ & $\begin{array}{l}\mathrm{H}_{\mathrm{vn}} \\
(\mathrm{m})\end{array}$ & $\begin{array}{l}\mathrm{H}_{\mathrm{dc}} \\
(\mathrm{m})\end{array}$ & $\begin{array}{l}\mathrm{N} / \mathrm{ha} \\
\text { (tree) }\end{array}$ & $\begin{array}{l}\mathrm{G} / \mathrm{ha} \\
(\mathrm{cm})\end{array}$ & $\begin{array}{l}\text { Biomass/ha } \\
\text { (tons) }\end{array}$ \\
\hline 1 & EB rich forest & 28.73 & 15.59 & 8.85 & 714 & 41.95 & 318.38 \\
\hline 2 & EB medium forest & 27.66 & 12.33 & 6.61 & 640 & 28.79 & 249.98 \\
\hline 3 & EB poor forest & 18.5 & 10.77 & 5.26 & 456 & 10.74 & 101.06 \\
\hline 4 & DD medium forest & 21.91 & 12.42 & 7.18 & 664 & 24.17 & 163.87 \\
\hline 5 & DD poor forest & 15.61 & 8.57 & 4.32 & 846 & 13.29 & 54.79 \\
\hline
\end{tabular}

\subsection{Land cover map of 2004}

Land cover map based on supervised classification of SPOT 2004 is shown in Figure 4 and area analysis of land cover is given in Table 4. The EB rich forest is $23,718.55$ ha $(20.53 \%)$, EB medium forest area is $21,198.38$ ha $(18.35 \%)$, EB poor forest area is $9,272.83$ ha $(8.03 \%)$, DD medium forest area is $53,205.46$ ha
$(46.05 \%)$, DD poor forest area is $7,176.22$ ha $(6.21 \%)$, Other land cover is 297.50 ha $(0.26 \%)$ and Water body area is 676.54 ha $(0.59 \%)$. The assessment results in classification accuracy in mapping forest cover from the SPOT in 2004 with the overall accuracy is $84.30 \%$, producer's accuracy is $86.74 \%$ and user's accuracy is $84.26 \%$.

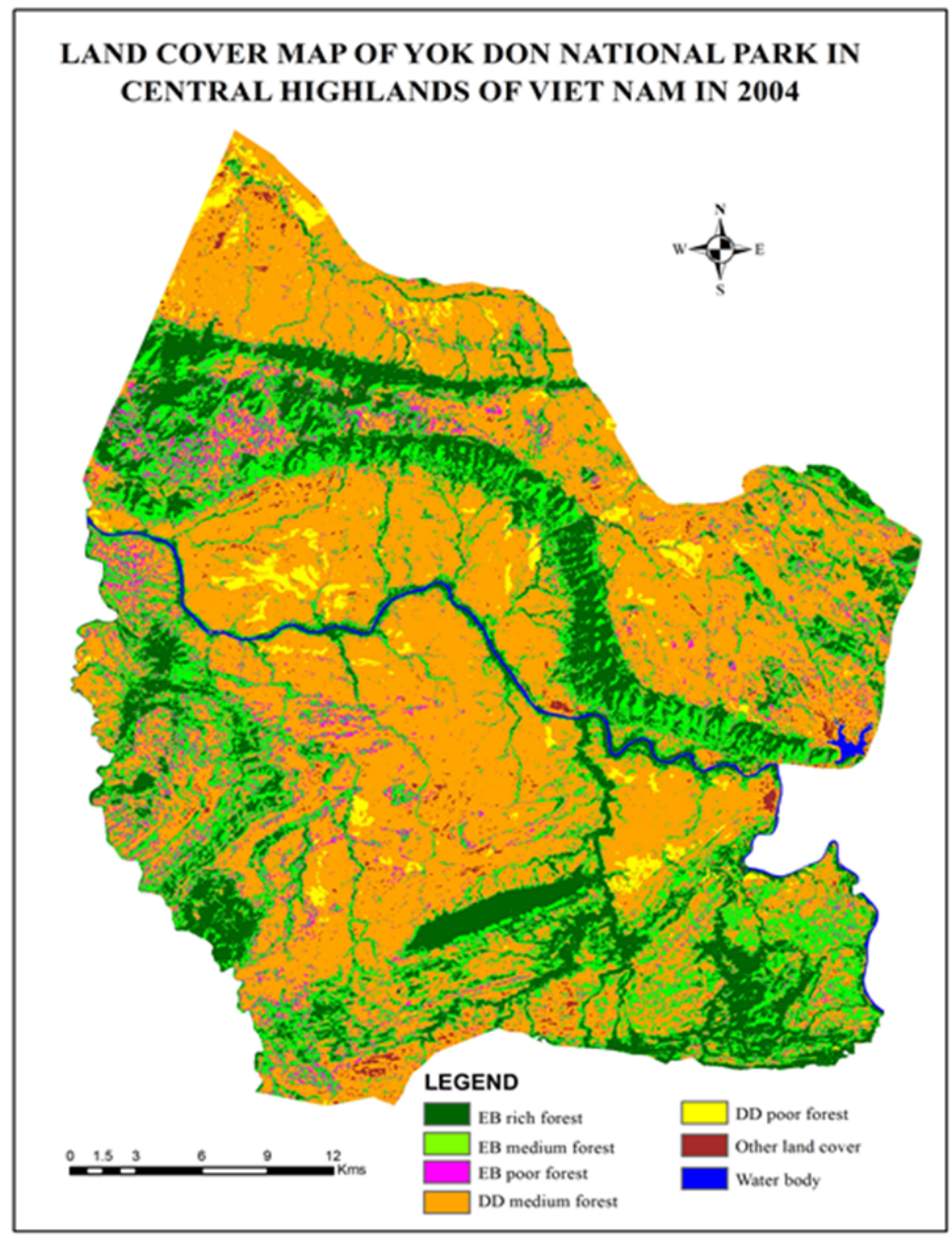

Figure 4. Land cover map in 2004 
Nguyen Viet Luong, et al./Vietnam Journal of Earth Sciences 36 (2014)

Table 4. Land cover area in 2004

\begin{tabular}{|c|c|c|c|c|c|}
\hline \multirow{2}{*}{ No. } & \multirow{2}{*}{ Class/Year } & \multicolumn{2}{|c|}{2004} & \multirow{2}{*}{$\begin{array}{c}\text { User's accuracy } \\
\text { Percent }(\%)\end{array}$} & \multirow{2}{*}{$\begin{array}{c}\text { Producer's accuracy } \\
\text { Percent }(\%) \\
\end{array}$} \\
\hline & & Area (ha) & Percent $(\%)$ & & \\
\hline 1 & EB rich forest & $23,718.55$ & 20.53 & 91.67 & 81.48 \\
\hline 2 & EB medium forest & $21,198.38$ & 18.35 & 72.00 & 78.26 \\
\hline 3 & EB poor forest & $9,272.83$ & 8.03 & 75.00 & 78.95 \\
\hline 4 & DD medium forest & $53,205.46$ & 46.05 & 92.59 & 80.65 \\
\hline 5 & DD poor forest & $7,176.22$ & 6.21 & 83.33 & 92.59 \\
\hline 6 & Other land cover & 297.5 & 0.26 & 80.00 & 95.24 \\
\hline 7 & Water body & 676.54 & 0.59 & 100.00 & 100.00 \\
\hline & Total & $115,545.48$ & 100 & & \\
\hline
\end{tabular}

\subsection{Land cover area of 2011}

The land cover map based on supervised classification for 2011 is shown in Figure 5 and the area statistics for land cover of 2011 is given in Table 5. The EB rich forest area is $14,425.79$ ha $(12.48 \%)$, EB medium forest area is $20,831.99$ ha $(18.03 \%)$, EB poor forest area is $11,583.99$ ha
$(10.03 \%)$, DD medium forest area is $39,724.39$ ha $(34.38 \%)$, DD poor forest area is $23,930.83$ ha ( $20.71 \%)$, Other land cover is $3,841.32$ ha $(3.32 \%)$ and Water body area is $1,207.63$ ha $(1.05 \%)$. The assessment results in classification accuracy in mapping forest cover from the SPOT in 2011 with the overall accuracy is $86.62 \%$, producer' accuracy is $87.34 \%$ and user accuracy is $84.77 \%$.

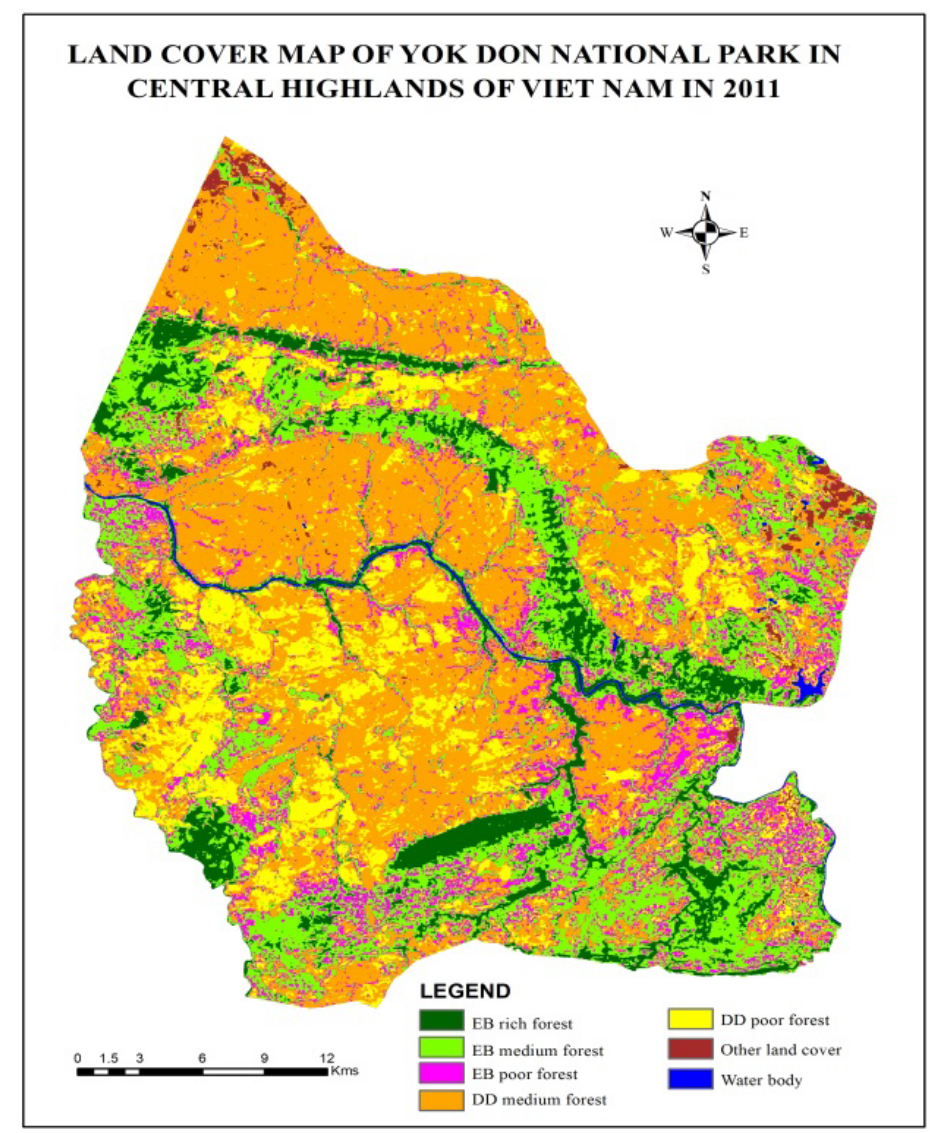

Figure 5. Land cover map in 2011 
Vietnam Journal of Earth Sciences 36 (2014) 439-450

Table 5. Land cover area in 2011

\begin{tabular}{|c|c|c|c|c|c|}
\hline \multirow{2}{*}{ No. } & \multirow{2}{*}{ Class/Year } & \multicolumn{2}{|l|}{2011} & \multirow{2}{*}{$\begin{array}{c}\text { User's accuracy } \\
\text { Percent }(\%) \\
\end{array}$} & \multirow{2}{*}{$\begin{array}{c}\text { Producer's accuracy } \\
\text { Percent }(\%) \\
\end{array}$} \\
\hline & & Area (ha) & Percent (\%) & & \\
\hline 1 & EB rich forest & $14,425.79$ & 12.48 & 91.30 & 81.48 \\
\hline 2 & EB medium forest & $20,831.53$ & 18.03 & 72.00 & 86.36 \\
\hline 3 & EB poor forest & $11,583.99$ & 10.03 & 78.95 & 88.89 \\
\hline 4 & DD medium forest & $39,724.39$ & 34.38 & 92.59 & 83.87 \\
\hline 5 & DD poor forest & $23,930.83$ & 20.71 & 83.33 & 86.96 \\
\hline 6 & Other land cover & $3,841.32$ & 3.32 & 80.00 & 100.00 \\
\hline \multirow[t]{2}{*}{7} & Water body & $1,207.63$ & 1.05 & 95.24 & 87.35 \\
\hline & Total & $115,545.48$ & 100.00 & & \\
\hline
\end{tabular}

\subsection{Land cover change map during 2004 to 2011}

The results of geospatial change maps from 2004 to 2011 based on post classification comparison method area is shown in Tables 6, 7, 8 and Figure 6 . The analysis indicates that the EB rich forest decreased by $9,292.76$ ha, EB medium forest decreased by 366.85 ha and DD medium forest decreased by 13,481.07 ha. While the EB poor forest increased by 2,311.16 ha and DD poor forest increased by 16,754.61 ha. The analysis also indicate that Other land cover increased by
3,543.82 ha and water body increased by 531.09 ha.

Table 6. Land cover area change during 2004 to 2011

\begin{tabular}{|c|c|c|c|c|}
\hline \multirow{2}{*}{ No. } & \multirow{2}{*}{ Class/Year } & 2004 & 2011 & Change $(+/-)$ \\
\hline & & Area (ha) & Area (ha) & Area (ha) \\
\hline 1 & EB rich & $23,718.55$ & $14,425.79$ & $-9,292.76$ \\
\hline 2 & EB medi & 21,19 & & -366.85 \\
\hline 3 & EB poor & 9,272 & .99 & $2,311.16$ \\
\hline 4 & DD med & 53,20 & $39,724.39$ & $-13,481.07$ \\
\hline 5 & DD poc & $7,176.22$ & $23,930.83$ & $16,754.61$ \\
\hline 6 & Other la & 297.5 & $3,841.32$ & $3,543.82$ \\
\hline 7 & Water body & 676.54 & $1,207.63$ & 531.09 \\
\hline & Total & $115,545.48$ & $115,545.48$ & 0.00 \\
\hline
\end{tabular}

Table 7. Area change matrix for the period 2004 to 2011 (units: ha)

\begin{tabular}{|c|c|c|c|c|c|c|c|c|c|}
\hline No. & Class/Year & $\begin{array}{c}\text { EB rich } \\
\text { forest } \\
\end{array}$ & $\begin{array}{c}\text { EB medium } \\
\text { forest }\end{array}$ & $\begin{array}{l}\text { EB poor } \\
\text { forest }\end{array}$ & $\begin{array}{l}\mathrm{DD} \text { medium } \\
\text { forest }\end{array}$ & $\begin{array}{l}\text { DD poor } \\
\text { forest }\end{array}$ & $\begin{array}{l}\text { Other land } \\
\text { cover }\end{array}$ & $\begin{array}{l}\text { Water } \\
\text { body }\end{array}$ & Total \\
\hline 1 & EB rich forest & $12,254.85$ & $7,586.79$ & $2,034.23$ & 650.74 & 550.55 & 414.77 & 226.62 & $23,718.55$ \\
\hline 2 & EB medium forest & $1,868.67$ & $9,597.1$ & $3,489.01$ & $3,173.85$ & $2,416.54$ & 499.38 & 153.83 & $21,198.38$ \\
\hline 3 & EB poor forest & 82.08 & $1,982.24$ & $3,884.41$ & $1,683.76$ & 1415.1 & 184.91 & 40.33 & $9,272.83$ \\
\hline 4 & DD medium forest & 147.23 & $1,431.76$ & $1,994.54$ & $32,473.5$ & $14,471.3$ & $2,258.25$ & 428.88 & $53,205.46$ \\
\hline 5 & DD poor forest & 17.46 & 110.26 & 144.69 & $1,637.14$ & $5,012.62$ & 231.26 & 22.79 & $7,176.22$ \\
\hline 6 & Other land cover & 1.66 & 62.8 & 29.93 & 94.01 & 50.31 & 50.83 & 7.96 & 297.50 \\
\hline \multirow[t]{2}{*}{7} & Water body & 53.84 & 60.58 & 7.18 & 11.39 & 14.41 & 201.92 & 327.22 & 676.54 \\
\hline & Total & $14,425.79$ & $20,831.53$ & $11,583.99$ & $39,724.39$ & $23,930.83$ & $3,841.32$ & $1,207.63$ & $115,545.48$ \\
\hline
\end{tabular}

Table 8. Area change distribution from 2004 to 2011

\begin{tabular}{llrl}
\hline No. & \multicolumn{1}{c}{ Class } & Area (ha) & Percent (\%) \\
\cline { 4 - 4 } \cline { 3 - 3 } 2 & No change area & $63,600.53$ & 55.04 \\
3 & Nositive change area & $10,004.1$ & 8.66 \\
& Total & $115,545.48$ & 100.00 \\
\hline
\end{tabular}

\subsection{Estimates of biomass and biomass change during 2004 to 2011}

The results of the estimation of biomass based on the data from the parameters of the structure of forest vegetation from Table 3 and land cover area from Table 4, Table 5, then application of the allometric equation (1) and allometric equation (2) above. The analysis indicates that the between 2004 and 2011, the biomass of Evergreen broad leaved rich forest decreased by 2.95 Megatons (from 7.45 Mega tons to 4.59 Mega tons), biomass of the Evergreen broad leaved medium forest decreased by 0.09 Mega tons (from 5.29 Mega tons to 5.20 Mega tons) and biomass of the Dry open dipterocarps medium forest decreased 2.20 Mega tons (from 8.71 Mega tons to 6.50 Mega tons). However, biomass of the Evergreen broad 
Nguyen Viet Luong, et al./Vietnam Journal of Earth Sciences 36 (2014)

leaved-poor forest increased by 0.02 Mega tons (from 0.93 Mega tons to 1.17 Mega tons) and biomass of the Dry open dipterocarps-poor forest increased by 0.91 Mega tons (from 0.39 Mega tons to 1.31 Mega tons). The total amount of biomass of the study area decreased by 4.10 Mega tons. The results is given in Table 9 and Figure $7,8,9$.

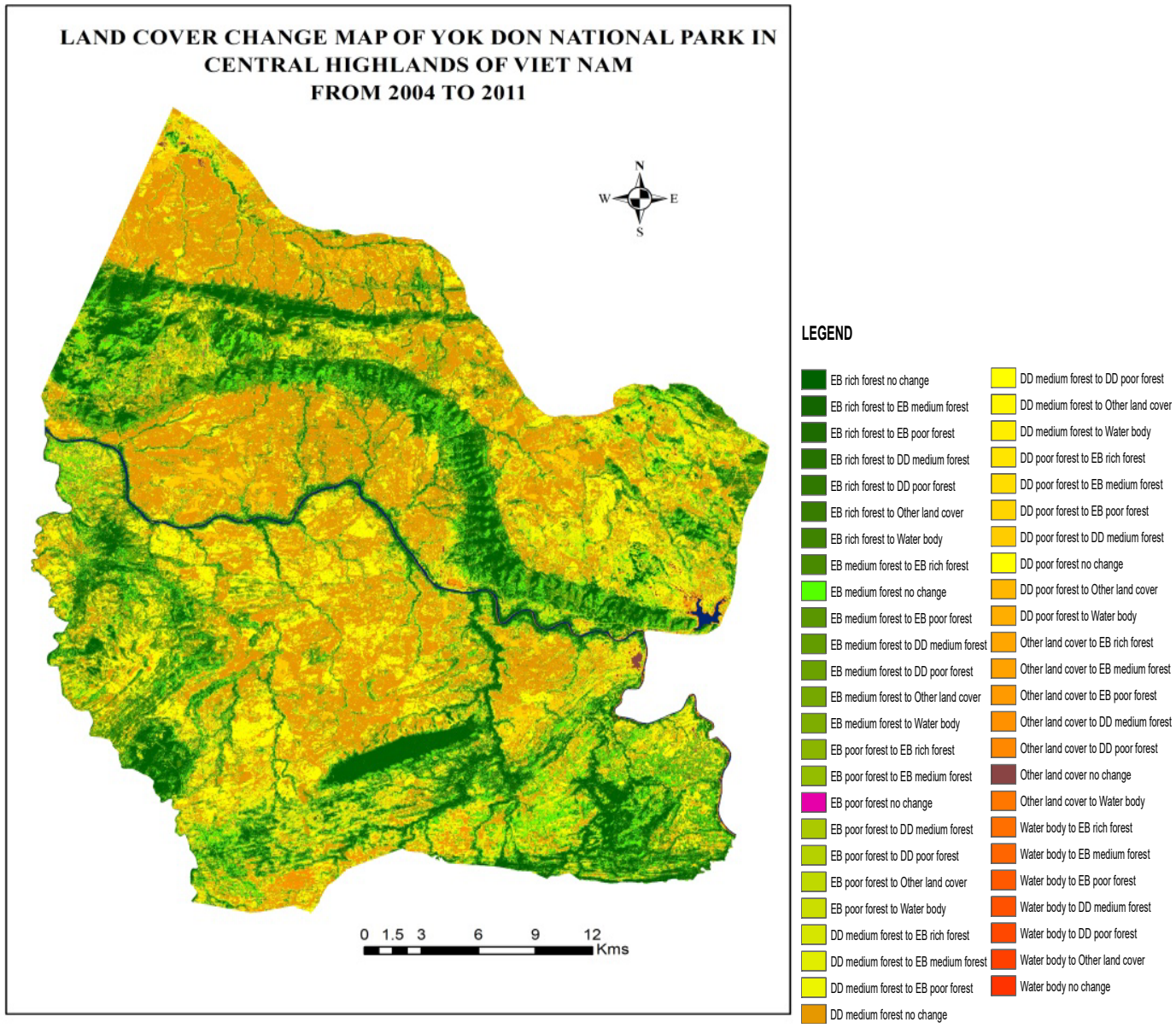

Figure 6. Land cover change map from 2004 to 2011

Table 9. Biomass and biomass change during 2004 to 2011

\begin{tabular}{|c|c|c|c|c|}
\hline \multirow{2}{*}{ No. } & \multirow{2}{*}{ Class/Year } & \multicolumn{2}{|c|}{ Biomass (tons) } & \multirow{2}{*}{ Change (+/-) } \\
\hline & & 2004 & 2011 & \\
\hline 1 & EB rich forest & $7,551,511.95$ & $4,592,883.02$ & $-2,958,628.93$ \\
\hline 2 & EB medium forest & $5,299,171.03$ & $5,207,465.869$ & $-91,705.16$ \\
\hline 3 & EB poor forest & $937,112.20$ & $1,170,678.029$ & $233,565.83$ \\
\hline 4 & DD medium forest & $8,718,778.73$ & $6,509,635.789$ & $-2,209,142.94$ \\
\hline \multirow[t]{2}{*}{5} & DD poor forest & $393,185.09$ & $1,311,170.176$ & $917,985.08$ \\
\hline & Total & $22,899,759.01$ & $18,791,832.88$ & $-4,107,926.12$ \\
\hline
\end{tabular}


Vietnam Journal of Earth Sciences 36 (2014) 439-450

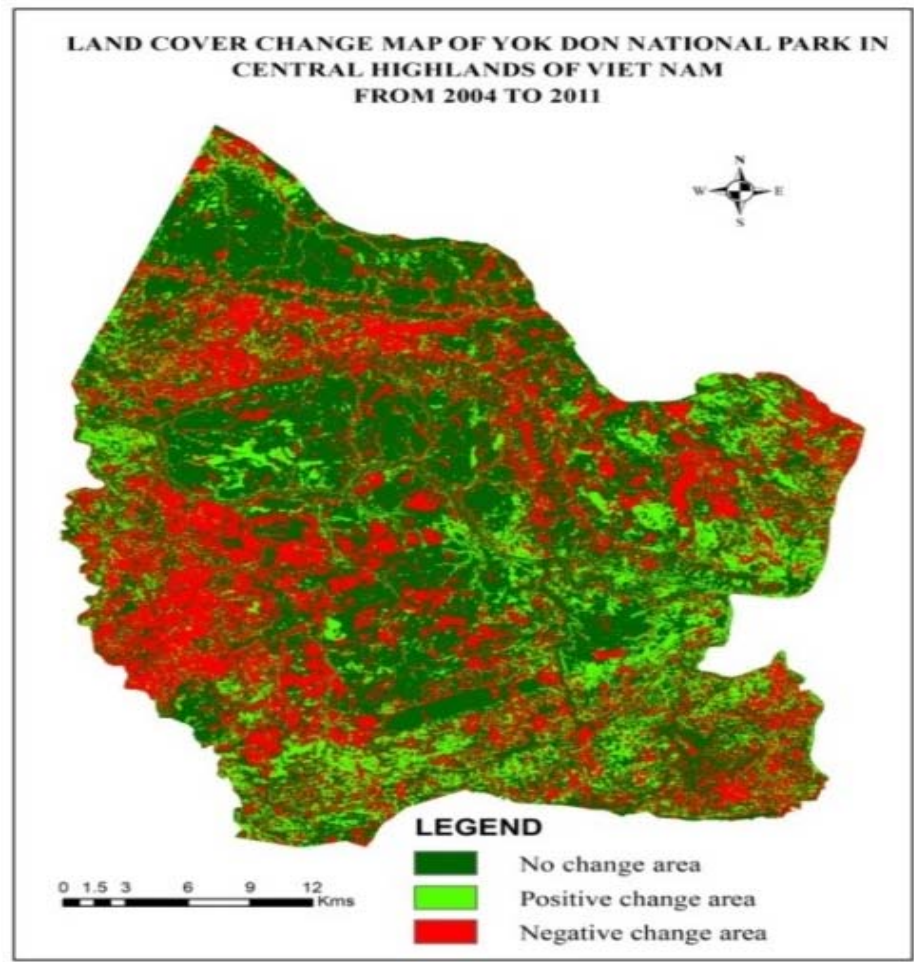

Figure 7. Land cover change map from 2004 to 2011

Figure 8. Biomass map in 2004

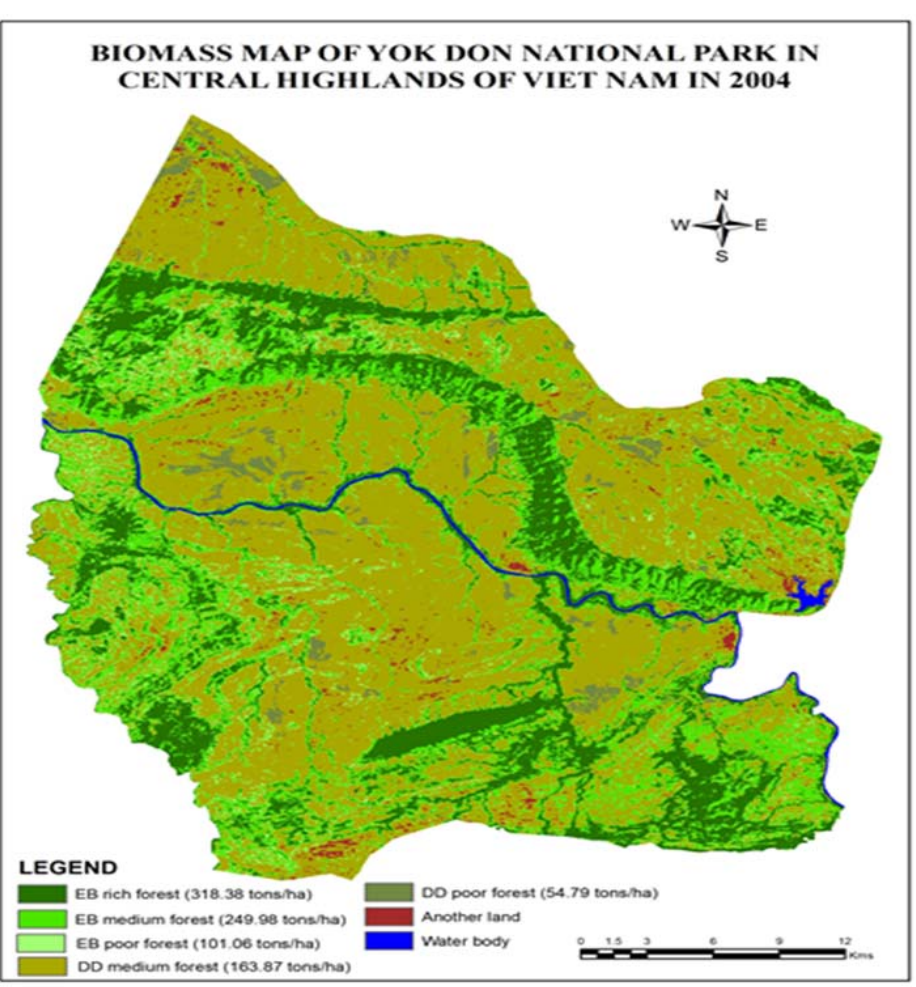


Nguyen Viet Luong, et al./Vietnam Journal of Earth Sciences 36 (2014)

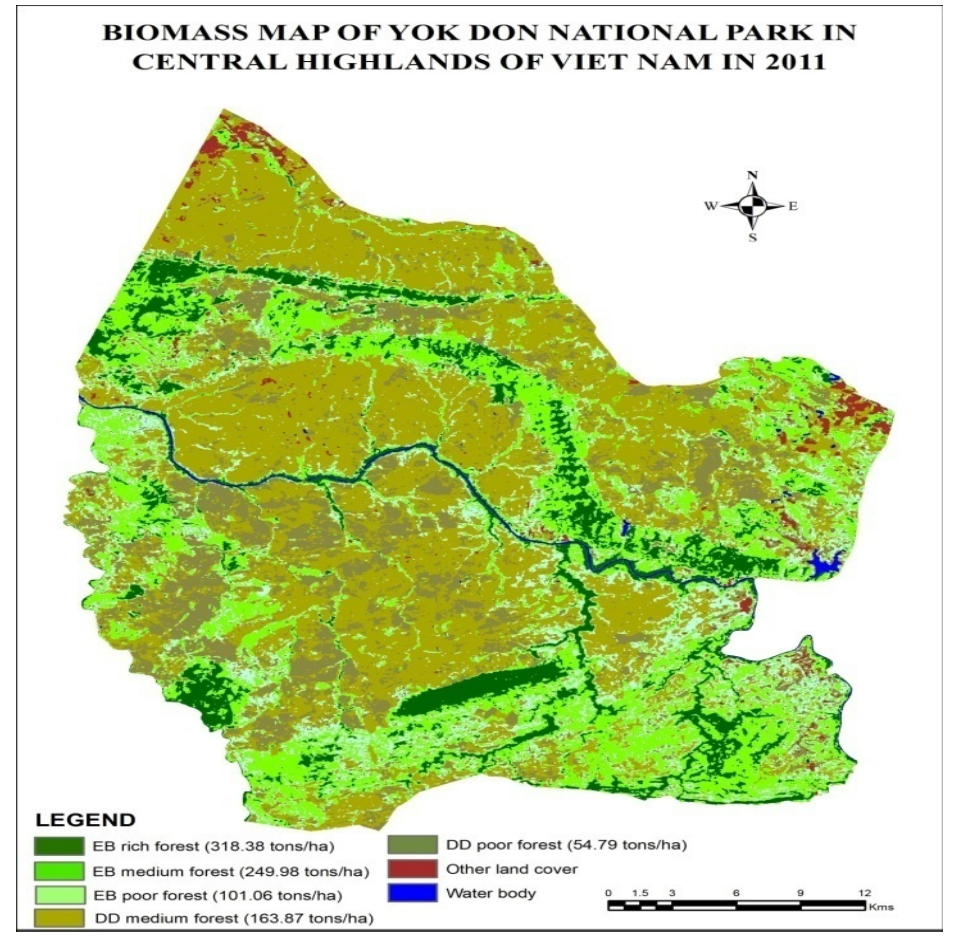

Figure 9. Biomass map in 2011

\section{Discussions}

From images of SPOT-5 with $10 \mathrm{~m}$ resolution, the application of the standard procedure of supervised classification approach has been applied followed by maximum likelihood algorithm classification and has demonstrated that it is of efficient and effective use for mapping of land cover with overall classification accuracy of $84.89 \%$ to $85.89 \%$. The analysis indicates that the between 2004 and 2011, the biomass of Evergreen broad leaved rich forest decreased by 2.95 Megatons (from 7.45 Mega tons to 4.59 Mega tons), biomass of the Evergreen broad leaved medium forest decreased by 0.09 Mega tons (from 5.29 Mega tons to 5.20 Mega tons) and biomass of the Dry open dipterocarps medium forest decreased by 2.20 Mega tons (from 8.71 Mega tons to $6.50 \mathrm{Mega}$ tons). However, biomass of the Evergreen broad leaved-poor forest increased by 0.02 Mega tons (from 0.93 Mega tons to 1.17 Mega tons) and biomass of the Dry open dipterocarps-poor forest increased by $0.91 \mathrm{Mega}$ tons (from 0.39 Mega tons to 1.31 Mega tons).The analysis of area change matrix indicated that the non-change area is 68.6 thousand ha $(55.04 \%)$, the positive change area is 10.0 thousand ha $(8.66 \%)$ and the negative change area is 41.9 thousand ha $(36.30 \%)$. Besides, much of those EB rich forest got converted to EB medium forest, EB poor forest and DD medium forest got converted to DD poor forest respectively. The total amount of biomass of the study area decreased by 4.10 Mega tons.

\section{Recommendations}

The optical sensor is spectral reflectance data collected in visible and infrared region. Thus, information from optical satellite imagery observed only information about the surface of the canopy. Therefore, the information extracted and correlation model derived from optical satellite images have been limited to the recorded information and describes information about the structure of land cover such as diameter, height of trees. So this is the indirect method for estimating biomass through the ground survey data. This method is applied in case we only have optical satellite imagery and ground survey data. In the future research, we will combine different data sources such as radar data for directly calculation 
Vietnam Journal of Earth Sciences 36 (2014) 439-450

and monitoring of biomass for forest vegetation. Based on the findings of this study the following recommendations:

- Using satellite images with high resolution for preparing land cover map and land cover change map will aid in monitoring forest conditions. Combining this information with the field data can also be useful for estimating biomass stock and sequestered carbon in the evaluation of the existing forest resources in terms of its ability to reduce carbon emission. We recommend biomass change analyses to be performed on a yearly base to monitor the forest's conditions and the ecosystem services it might provide.

- Creating a permanent sample plot network (in accordance with existing standards and sufficient in number) in the forested areas so that a consistent sample can be obtained for monitoring forest status annually.

- The estimate of forest biomass used in this study is the estimation methods indirectly using optical satellite imagery and ground survey data. The direct calculation of forest biomass and biomass monitoring as well as carbon storage and $\mathrm{CO}_{2}$ sequestration should be used combined with satellite radar images

\section{Acknowledgements}

The authors are highly grateful to the project No. VAST01.03 15-16 from Vietnam Academy of Science and Technology (VAST) and Japan Society for the Promotion of Science (JSPS) have supported, encouraged and provided funding for this study.

\section{Reference}

Bao Huy, 2008: Methodology for research on $\mathrm{CO}_{2}$ sequestration in natural forests to join the program of reducing emission from deforestation and degradationREDD. Journal of Agriculture and Rural Development, MARD, 2008, pp. 1-10.

Bhishma, P. et al., 2010: Forest carbon stock measurementGuidelines for measuring carbon stocks in communitymanaged forest. Asia Network for Sustainable Agriculture and Bioresource (ANSAB), 79 pp.

Brown, S., 1997. Estimating biomass and biomass change of tropical forests: a Primer. FAO Forestry paper-134. ISBN 92-5-103955-0.
Brown, S., 2002: Measuring carbon in forests: current status and future challenges. Environmental Pollution, 116(3): 363-372.

Canh N. X. et al., 2009: Conservation planning and Sustainable Development of Yok Don National Park in 2010-2020, $150 \mathrm{pp}$.

Chaiyo, U., Garivait, S., Wanthongchai, K., 2011: Carbon storage in Above-Ground Biomass of Tropical Deciduous Forest in Ratchaburi Province, Thailand. World Academy of Science, Engineering and Technology, pp. 636-641..

Chave, J., Andalo, C., Brown, S., Cairns, M.A. et al., 2005: Tree allometry and improved estimation of carbon stocks and balance in tropical forests. Oecologia Vol. 145, No. 1, pp. 87-99.

Guide to the Kyoto Protocol to United Nations framework convention on climate change, 1998.

Howarth, Wickware, 1981: Spatial analysis of land cover and land use in evaluating land degradation in Northwestern Al-Mafraq city, Jordan, pp. 55-62.

IPCC, 2003: Good Practice Guidance for Land Use, Land-Use Change and Forestry. IPCC National Greenhouse Gas Inventories Programme Technical Support Unit. Printed in Japan. ISBN 4-88788-003-0.2003, 590pp.

IPCC, 2006: Guidelines for National Greenhouse Gas Inventories. Volume 4: Agriculture, Forestry and Other Land Use. Chapter 4. Forest land, 83 pp.

Losi, C.J. et al., 2003: Analysis of alternative methods for estimating carbon stock in young tropical plantations. Forest Ecology and Management, 184(1-3): 355-368.

Lu, D. S., 2006: The potential and challenge of remote sensingbased biomass estimation. International Journal of Remote Sensing. Vol. 27, No. 7, 1297-1328.

Luong, N.V., 2011: Essay to use remote sensing images to estimate biomass as a basis for calculating the amount of $\mathrm{CO}_{2}$ sequestration by vegetation cover in in Yok Don National Park, Highlands of Viet Nam.Scientific Conference "Research, development and application of space technology-2011".ISBN: 987-604-913-032-8. Hanoi. 9pp.

Ministry of Agriculture and Rural Development (MARD). Circular 34/TT-BNN issued by (MARD) of Vietnamese government, 2009: Quy định tiêu chí xác định và phân loại rừng (in Vietnamese), translated by Luong N.V-Regulation on criteria for identifying and classifying forest (in English), 5, 3 . 
Nguyen Viet Luong, et al./Vietnam Journal of Earth Sciences 36 (2014)

Phat, N.K. et al., 2004 : Appropriate measures for conservation of terrestrial carbon stocks- Analysis of trends of forest management in Southeast Asia. Forest Ecology and Management, 191(1-3): 283-299.

Thin, N. N. et al., 2007: The vegetation of Yok Don National Park, a special ecosystem in Central Highlands of Vietnam, 2007, 6, 4-5.

Trung, T. V.The tropical forest ecosystem in Vietnam.Science and Technics Publishing House, Hanoi. Chapter IV, 1998, $291 \mathrm{pp}$.

Trung, T.V.The vegetation cover in Vietnam. Science and Technics Publishing House, Hanoi. Chapter IV, V, 1978: $276 \mathrm{pp}$.
UNESCO Paris, 1973. International classification and mapping of vegetation. Published by the United Nations Educational, Scientific and Cultural Organization. ISBN 92-3-001046-4 LC No. 72-96442, 1973, 102pp.

UN-REDD in Vietnam programme, 2012: Guidelines on Destructive Measurement for Forest Biomass Estimation for technical staff use. (Version for discussion).

UN-REDD Vietnam Programme, 2012: Tree allometric equation development for estimation of forest aboveground biomass in Viet Nam. Part A - Introduction and Background of the Study Viet Nam. 